\title{
Rescue archaeological research on the Dominican Square in Cracow in the light of interdisciplinary studies
}

\author{
Monika Łyczak \\ FRAMEA Archaeological Company; ul. Na Kozłówce 4a/10, 30-664 Krakow; e-mail: archeogia@framea.pl
}

(c) 2014 Authors. This is an open access publication, which can be used, distributed and reproduced in any medium according to the Creative Commons CC-BY 4.0 License requiring that the original work has been properly cited.

Received: 10 September 2013; accepted: 17 March 2014

\begin{abstract}
The rescue excavations associated with the renovation of surfaces surrounding the Dominican Basilica of the Holy Trinity in Cracow were conducted in 2011-2012 in front of the church. This research confirmed the presence of a churchyard cemetery whose origins date back to the $12^{\text {th }}$ century and led to the discovery of previously unknown relics of medieval architecture in the form of two pieces of the masonry foundation of the Gothic chapels and presumably pre-Dominican (or early-Dominican) church of the Holy Trinity as well as undisturbed culture layers from early mediaeval times.

The research was carried out in close collaboration with researchers in architecture and art history; it enabled preliminary reconstruction of the plans of the discovered buildings. Petrographic analysis of building material and samples of mortars used provided information on mediaeval construction techniques.

Human bone material was analyzed by anthropologists. As a result, the gender, age and health status of members of the mediaeval and modern populations of Cracow buried in the cemetery were determined. Geochemical studies also helped to assess the degree of land contamination related to the presence of the cemetery. A detailed analysis of the cultural layer representing the residue of the open settlement along with its coeval economical structures was carried out. Layer dating was based on a formal analysis of the ceramic material. Osteological research of the animal bone material and palaeobotanical studies of soil samples taken from settlement layers allowed clarification of the nature of the settlement.
\end{abstract}

Keywords: medieval architecture, archaeological excavations, cultural layer, petrographic and geochemical studies

\section{INTRODUCTION}

Modern Dominican Square is located within the boundaries of the Medieval Cracow's city charter urban arrangement, directly to the north of the duke's suburbium named Okót. Archaeological reconnaissance exploration carried out last century in the form of survey excavations and geotechnical drilling indicated the presence of pre-city charter settlements in this area (Radwański 1975: 150-154, Rajman 2004: 41-43, Zaitz 2006: 229), while numerous historical sources provided information on the post-city charter history of the Square. According to these, at the beginning of the $13^{\text {th }}$ century the Dominican Monks who arrived in Cracow received the Holy Trinity parish church, already existing on this site, from the bishop of Cracow, Iwo Odrowąż. They reconstructed this church over the following period in Gothic style (ZDKK: 16-17, Długosz 1863-1864: 449, 1964-1974: 235, Rocznik kapituly... 1978: 73). Written and iconographic sources also suggested the presence of an early-medieval churchyard in the subject area; however, its existence had not been confirmed by any 
field research. The monastery necropolis, both of late mediaeval and modern times, was documented during rescue studies conducted in the ambulatory in the 1970s (Myszka 2003: 136 - Fig. 2, Zaitz 1974: 236-238, Radwańska et al. 1975: 187-188).

Deterioration of the Square pavement in recent years has led to the decision on general renovation which will be carried out by the Conservation Company Piotr Białko Sp. z o.o., and funded by the Social Committee for the Restoration of Historic Monuments in Cracow. One of the elements concurrent with the renovation work was the archaeological supervision of earthworks associated with the pavement replacement, the repair of small architectural elements, and the introduction of a ramp for the disabled people.

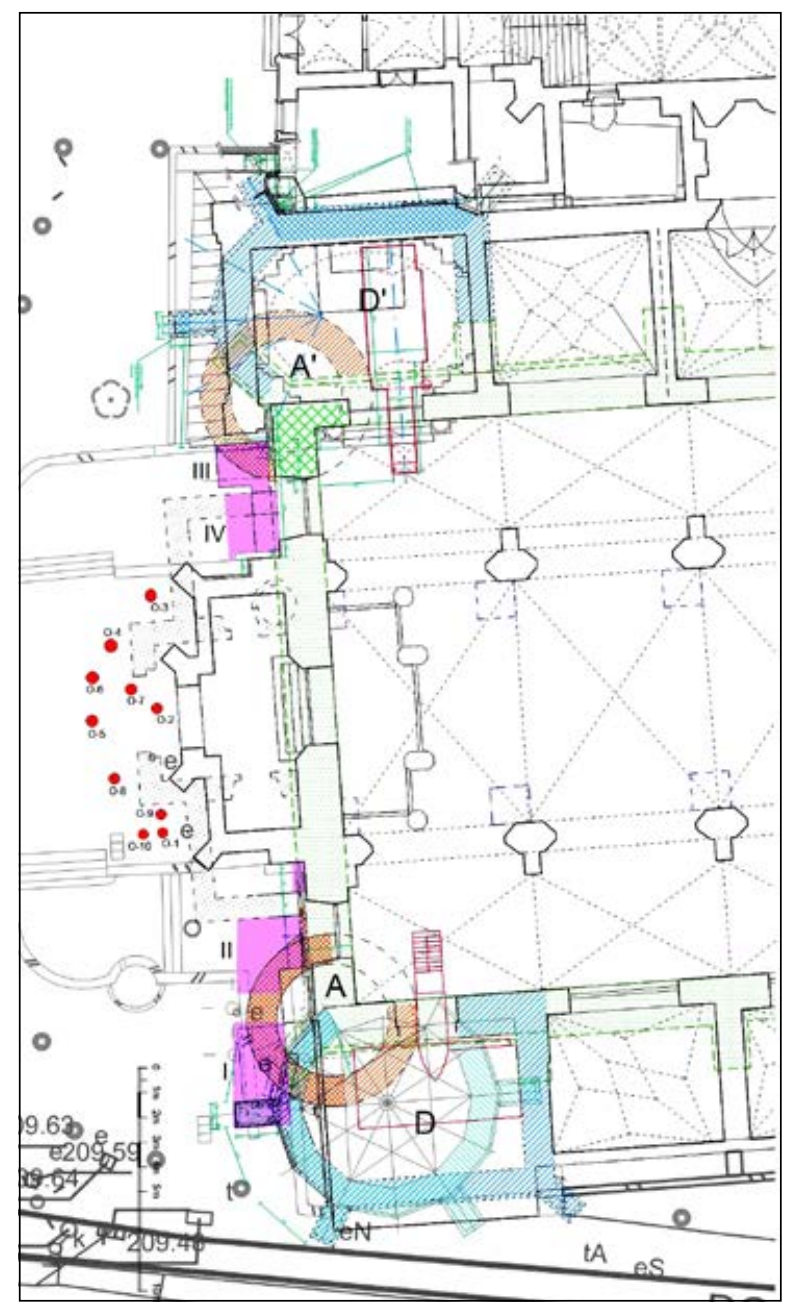

Fig. 1. Localisation of the relics discovered and geotechnical drilling conducted: $I-I V$ - archaelogical trenches, O-1 - O-10 - geotechnical drillings, A-A' - towers of presumably pre-Dominican church of Trinity, D-D' - gothic burial chapels; architectural features - M. Goras, W. Niewalda, geotechnical drilling - S. Kuczera
However, on the first day of work it turned out that the discovery of some unknown remains which were exposed in the course of the earthworks required more extensive research. As a result, in addition to the supervision comprising the entire surface of the Dominican Square, four small archaeological research trenches were executed (Fig. 1). These were located in the vicinity of the side aisles of the church, and near the chapels of St. Rose of Lima (Lubomirski's), and St. Catherine of Siena (Zbaraski's) (Łyczak \& Górski 2011: 3-92, 2012a, 2012b: 3-86, 2013). The archaeological survey was carried out by the Archaeological Company FRAMEA - Monika Łyczak.

\section{SURVEY RESULTS}

Due to the specific nature of the site, the excavation works were executed in close co-operation with the following architecture and history of art researchers: Waldemar Niewalda, Halina Rojkowska and Magdalena Goras. Detailed architectural and historical analysis enabled the updating of certain information concerning the history of the Trinity church - both in terms of the pre-Dominican period and particular phases of the Dominican construction located in the western façade of the church. Ongoing attempts to reconstruct the objects discovered were also made, but due to the limited scope of the research (including the necessary hammering of the surface in narrow drainage channels), and the partial preservation of the relics, the subsequent discoveries meant that in some cases (such as Pilecki's Chapel) it was necessary to introduce substantial alterations to the original reconstructions. There is no question that all previous hypotheses and suggestions will be subject to further historical testing and verification in the near future (Niewalda \& Rojkowska 2012, Rojkowska 2013).

The most important issue from the research point of view was the discovery of a presumably pre-Dominican structure, now considered most probably to be late Romanesque, whose foundation sections were used during the construction of the Dominican church (Fig. 2). However it cannot be also excluded that the revealed remains were built (or partly rebuilt from older building) as an original early-Dominican investment. This structure - with the façade over $24 \mathrm{~m}$ wide - was flanked by two massive, corner towers approximately $7 \mathrm{~m}$ in 
diameter. After the stratigraphic and architectural analysis, the preserved elements - the foundation remains of the western façade and the two corner towers - seemed to result from two different construction phases. The presence of early-mediaeval burials indicated this; the graves were probably connected to the original parish church of the Trinity, and - to a large extent - had been destroyed by the foundations of the round towers. It was also indicated by the lack of ties between straight masonry and towers in the foundation section, and minor differences in the depth of setting of various elements of the building.
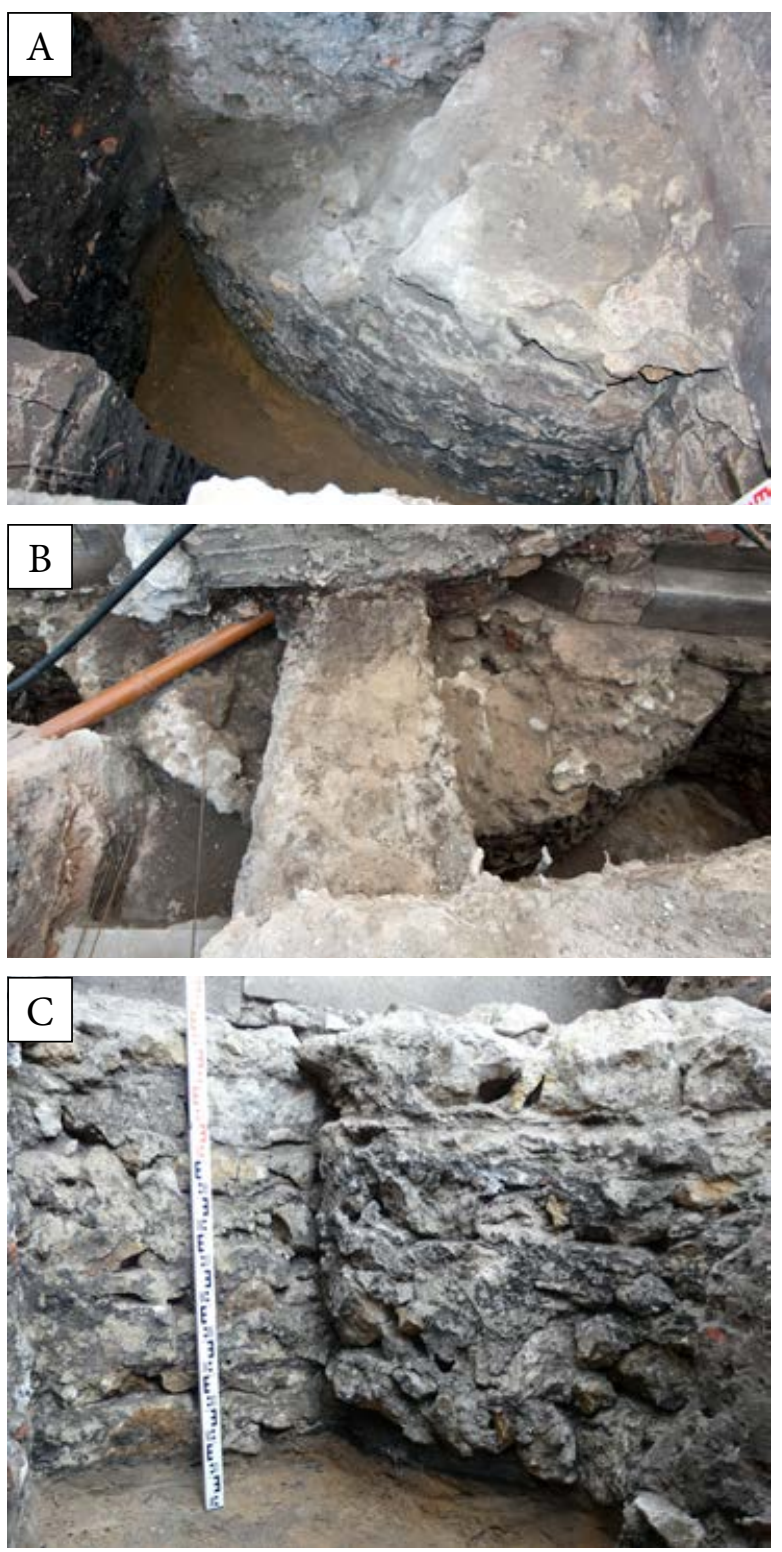

Fig. 2. West facade corner towers of the presumably pre-Dominican church of Trinity: A) north tower; B) and C) south tower; photo: $B$ - J. Dąbrowski
In order to clarify the construction phases of the church, it was decided to perform a petrographic analysis of the masonry stone and materials used for the production of mortars, which were collected from a number of locations in the walls. The analysis was executed by Maciej Pawlikowski from the AGH University of Science and Technology in Cracow (Pawlikowski 2011: 93-118, 2012: 87-109). The results of the laboratory tests showed that all the collected samples represented lime mortar; the proportions of its components used in the mortar of the west wall and north tower are very different from those used in the south tower (Figs 3, 4). Minor differences in the component proportions of the mortar were also observed in the upper and lower parts of the south tower, and the north and south sections of the straight masonry.
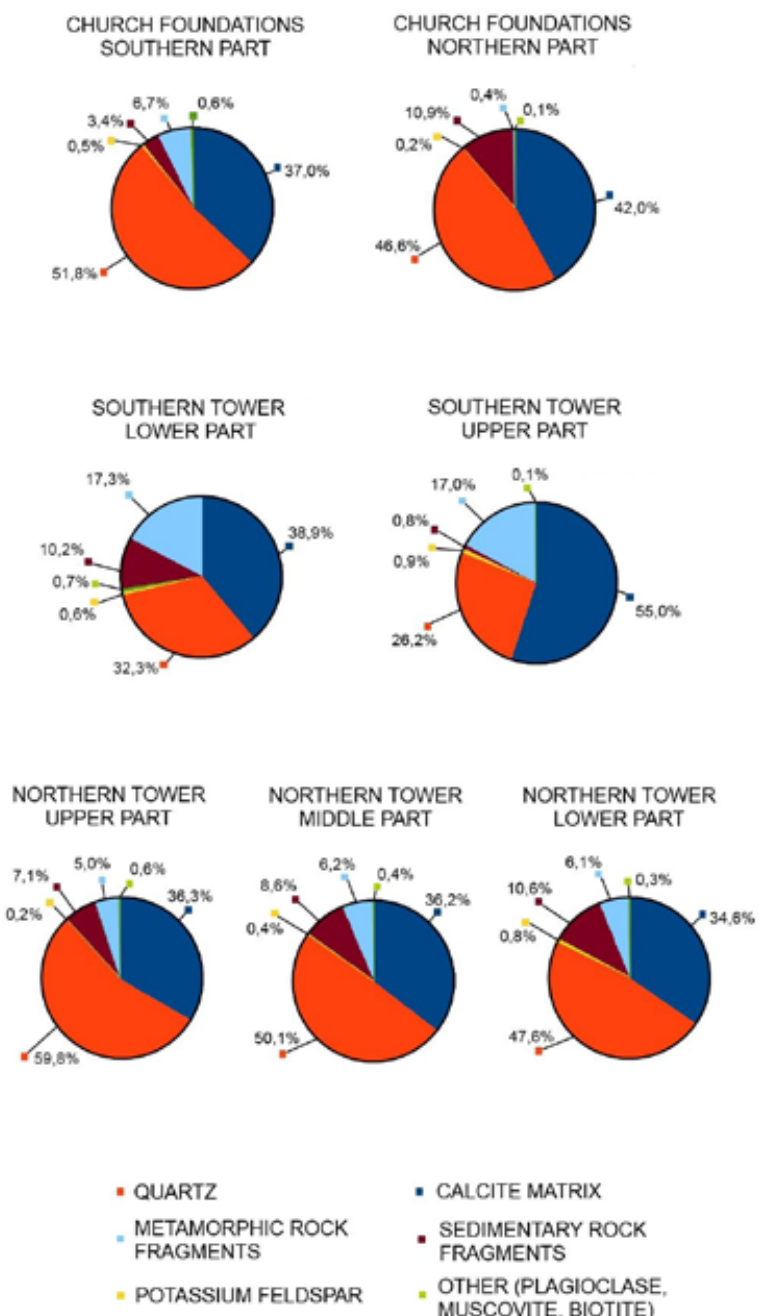

$$
\begin{aligned}
& \text { - CALCITE MATRIX } \\
& \text { - SEDIMENTARY ROCK } \\
& \text { FRAGMENTS } \\
& \text { - OTHER (PLAGIOCLASE, } \\
& \text { MUSCOVITE, BIOTITE) }
\end{aligned}
$$

Fig. 3. The results of mineralogical analysis of the collected mortars; tables - M. Pawlikowski 


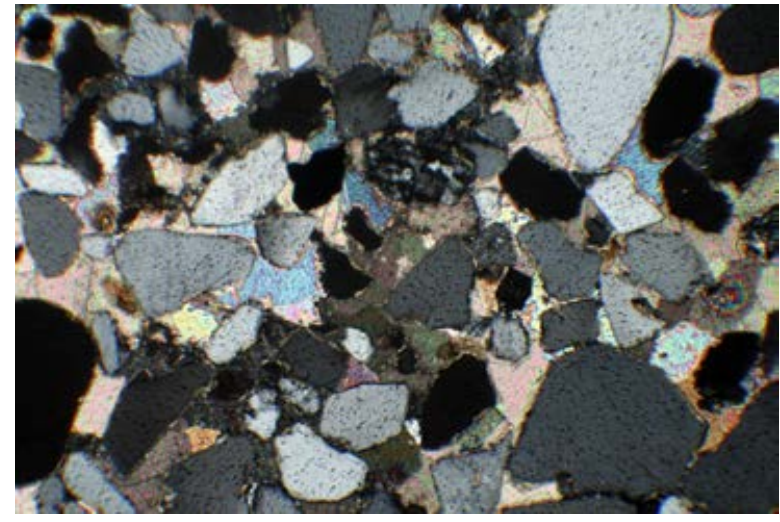

Fig. 4. Microscopic image of mortar - polarizing microscope, enlarging $80 \times$; crossed polars photo - M. Pawlikowski

The issue of possible phasing of the church construction would therefore require further petrographic studies and comparison of a larger number of representative samples.

Based on petrographic thin section, it was confirmed that all exposed parts of the pre-Dominican building were made of organodentric limestone with Pińczów limestone characteristics (Fig. 5), and not of the local Jurassic limestone, which was used to erect other Romanesque churches in Cracow. The stone was used in the construction industry due to its specific properties: when resting in the deposit it is soft and susceptible to processing, while when excavated, pre-treated and dried, it hardens, and noticeably increases in strength.

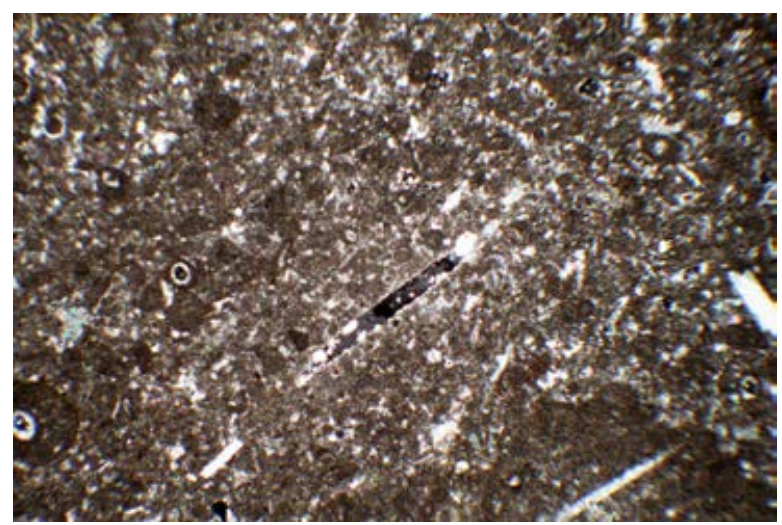

Fig. 5. Organodentric limestone with Pińczów limestone characteristics; plane polarized light photo - M. Pawlikowski

A comparative analysis - conducted simultaneously with the laboratory tests - of analogous, or architecturally similarly constructed western sections of early-mediaeval Romanesque churches, showed that apart from the two corner towers on the west side of the church there could (but did not have to) be an apse (e.g. the Church of St. Cyriak in Gernrode) or a portal (e.g. the Church of St. Chrysantus and Daria in Bad Münstereifel).

Due to the above, it was decided to execute geotechnical probe drillings in the area located in front of the nave, and the neo-gothic porch, which were carried out by Sylwester Kuczera (Kuczera 2012: 110-139). Owing to the presence of the abovementioned porch, and the conduct of very broad (engineering) excavations related to its construction filled with rubble stone and brick, and considering the relics presumed to be of a Baroque porch, the probe surveys were conducted in the central part of the square (Fig. 1). The results did not reveal any evidence of any additional architectural elements in the western section of the church, neither in the form of walls, nor as a sunken room (crypt). This may indicate their absence, but it may also be that the possible apse was quite small, and that its walls were destroyed completely by the foundations of the Baroque and neo-Gothic porch. The drillings in the central part of the Dominican Square confirmed the presence of culture layers similar to those already discovered in archaeological excavations in the survey of the north and south of the site, and the possible remains of a hardened public level in the form of a limestone pavement (floor finish?) or lime mortar floor in the central part of the square. It was also discovered that the original level of the natural ground in the area covered by the archaeological research works was at 206.50-207.00 $\mathrm{m}$ above sea level.

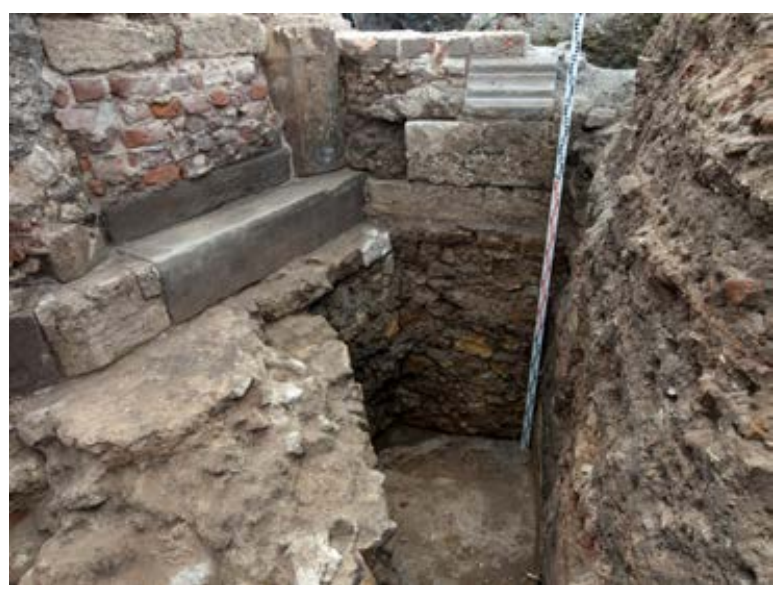

Fig. 6. Relics of gothic burial chapel of Pilecki family (Royal Chapel); photo - J. Dabrowski 


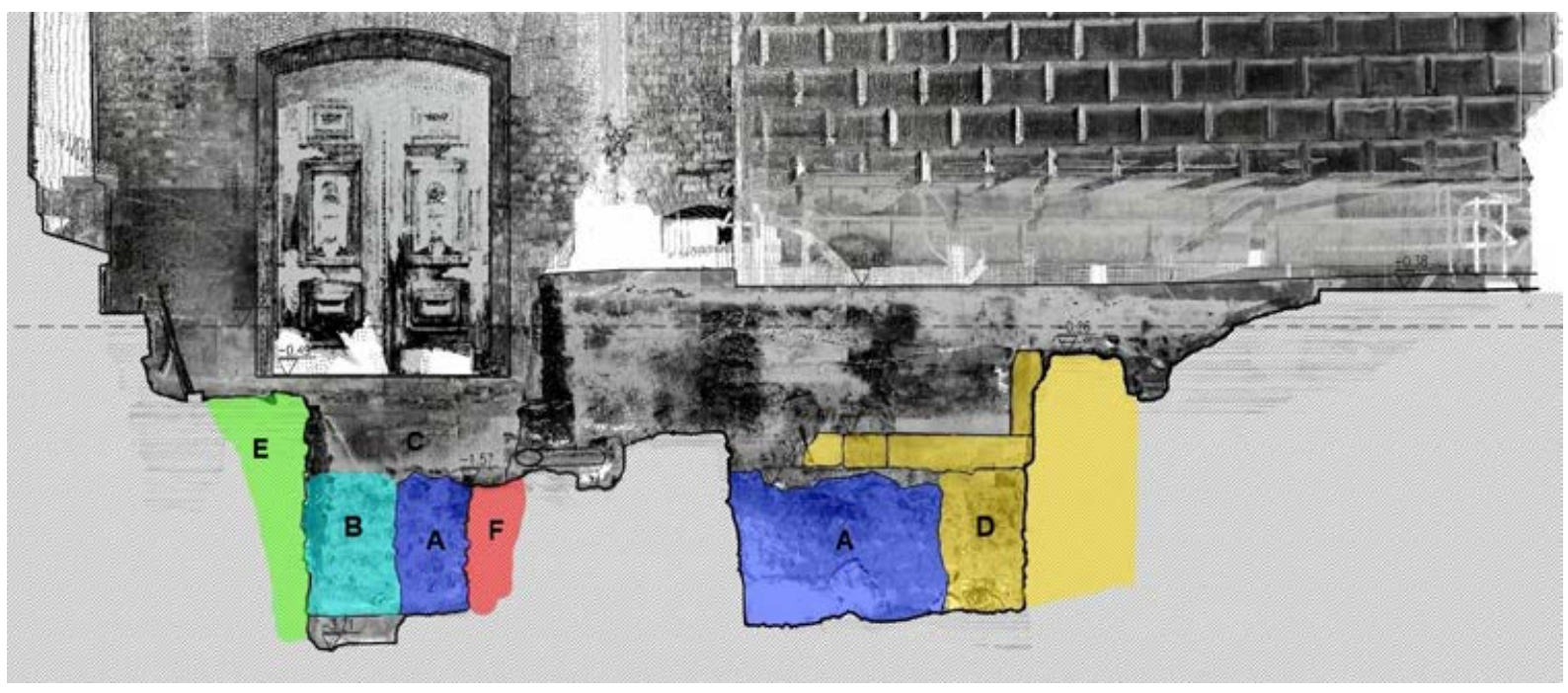

Fig. 7. Three-dimensional laser scanning of the architectural relics: $A$ - foundations of corner tower, $B$ - foundations of western facade of St. Trinity church, D - relics of burial chapel of the Pilecki family (Royal Chapel), E-foundation of the Holy Transfiguration chapel, F- unidentified modern wall; graphics - P. Turkiewicz

The archaeological and architectural studies conducted over the last two years also revealed relics of the unpreserved corner buttresses of a Gothic church, as well as two Gothic (the $14^{\text {th }}$ century) polygonal chapels (including the socalled Royal Chapel, founded by King Casimir the Great (Szyma 2012) - the later burial chapel of the Pilecki family (Fig. 6), a Baroque porch with two dome chapels (of the Holy Transfiguration and St. Anthony), and probably the remains of an earlier building of the monastery gate. The results of recent architectural discoveries are being processed (Niewalda \& Rojkowska 2012, Rojkowska 2013). In order to develop the most accurate inventory, a three-dimensional laser scanning of the architectural, listed relics discovered was carried out (Turkiewicz 2011, 2012) (Fig. 7). In addition, in connection with the discoveries made in the first season of research, prior to the second season, the study interest focused on the central and northern parts of the Dominican Square and a GPR survey of this area was conducted (Nawrocki 2011). It aimed at making a preliminary diagnosis regarding the soil, and projecting the location of archaeological excavations and architectural research trenches in places where potential relics from the oldest architecture were expected. Subsequent reconnaissance work within the drainage channel in front of the St. Catherine chapel facade confirmed the existence of Gothic chapel buttresses, which were registered by GPR.
Another important research matter which has been clarified thanks to the studies supporting the Square renovation is the churchyard cemetery located in the subject area (Łyczak \& Górski 2011: 8-15, 2012b: 9-13, 24-31, 37-38). During the two research seasons, both intact burials and ossuaria created on purpose were discovered, as well as destructive layers containing the damaged remains of tombs in the form of interspersed human remains. Unfortunately, the funeral customs of the Middle Ages practised in the churchyard cemeteries demanded that the dead be interred in the graves without any personal belongings (such as jewellery or clothing); solely wrapping in a shroud was applied, which considerably hinders both burial dating and determination of the deceased's social status. Stratigraphic analysis and dating of ceramic material found in the grave pits enabled only the oldest graves, related to the early mediaeval phase of the cemetery operation (the $12^{\text {th }}-13^{\text {th }}$ century) to be distinguished, and to set a framework dating for the late mediaeval, and modern cemetery period from the $13^{\text {th }}$ to the $18^{\text {th }}$ century (Figs 8,9 ). The only relic of burial equipment in this cemetery was a modern (the $16^{\text {th }}-17^{\text {th }}$ century?) rosary made of glass beads, and fitted with a Caravaca cross (Fig. 10).

A very important addition to the archaeological work are the anthropological analyses of skeletal remains prepared by Anita Szczepanek from the Department of Anthropology of the Jagiellonian University (Szczepanek 2011: 119-148, 2012: 150-154). 


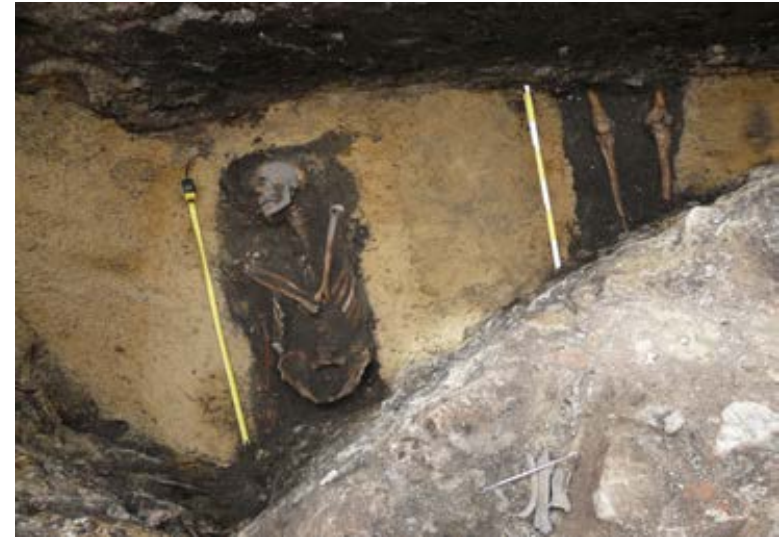

Fig. 8. Early-medieval burials

The analyses covered all the human bones - from both preserved graves and graves damaged in different periods of time. To date, the analyses of the material collected in 2011 in the southern part of the square have been completed. In the above mentioned material, the remains have been identified of about 50-60 individuals (preserved mainly in parts) - men, women, and children of all ages (including perinatal death). Due to the fragmentary nature of the analyzed material and the difficulty in dating it (particularly bones coming from interspersed layers), no chronological division of the analyzed specimens was made. Based on estimates it was only established that the in vivo adult female body height ranged $152-160 \mathrm{~cm}$, while male body height was between $155-170 \mathrm{~cm}$. Among pathological conditions observable in the preserved bone material, numerous teeth tartar deposits were noted, advanced caries (including milk teeth), strong abrasion in the area of adult teeth, and relatively common periapical inflammation of roots. Various degenerative changes in the bones of the postcranial skeleton were also often found (i.e. osteophytes, Schmorl's nodules, inflammation of bones (osteomyelitis), osteoarthrosis, or osteochondrosis).

Bone pathology was revealed particularly strongly in case of an early-mediaeval burial of a man (skeleton A), who died at the age of maturus-senilis (over 50 years); lesions of the spine and entesopathy of lumbar nodule and olecranon indicate that he suffered from diffuse idiopathic hyperosteosis of some skeleton bones (Forestier's disease). This disease is characterized by hyperplasia of bone in areas of muscle, tendon, and joint attachments, and characteristic changes within the lower thoracic vertebrae, i.e. presence
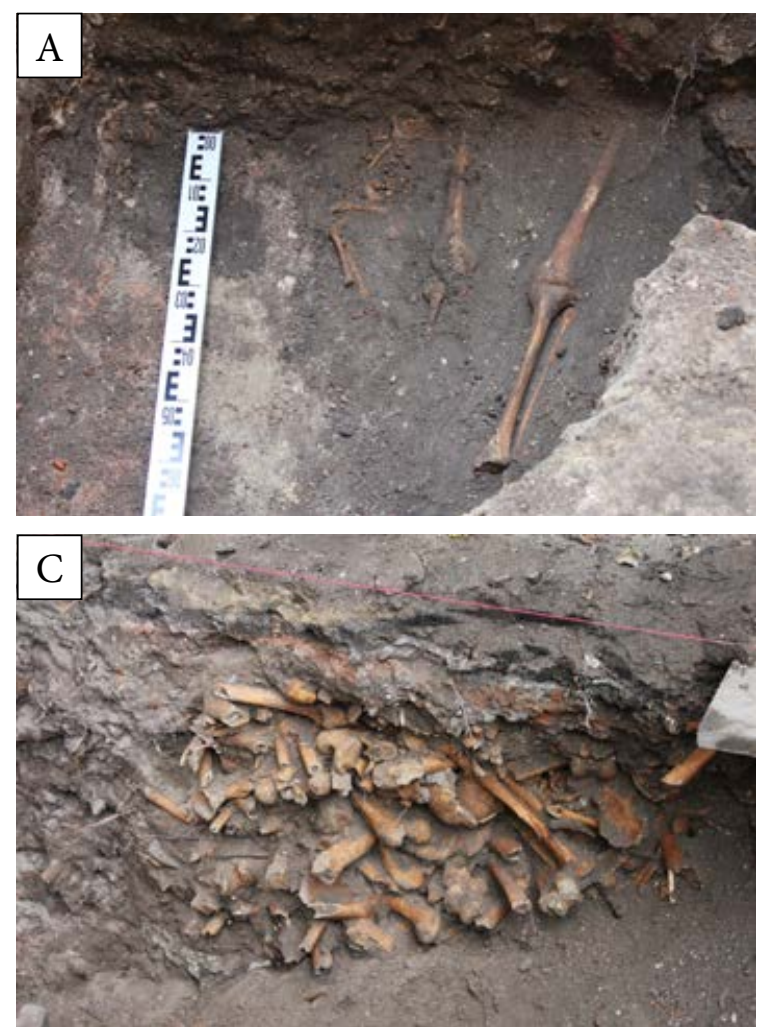

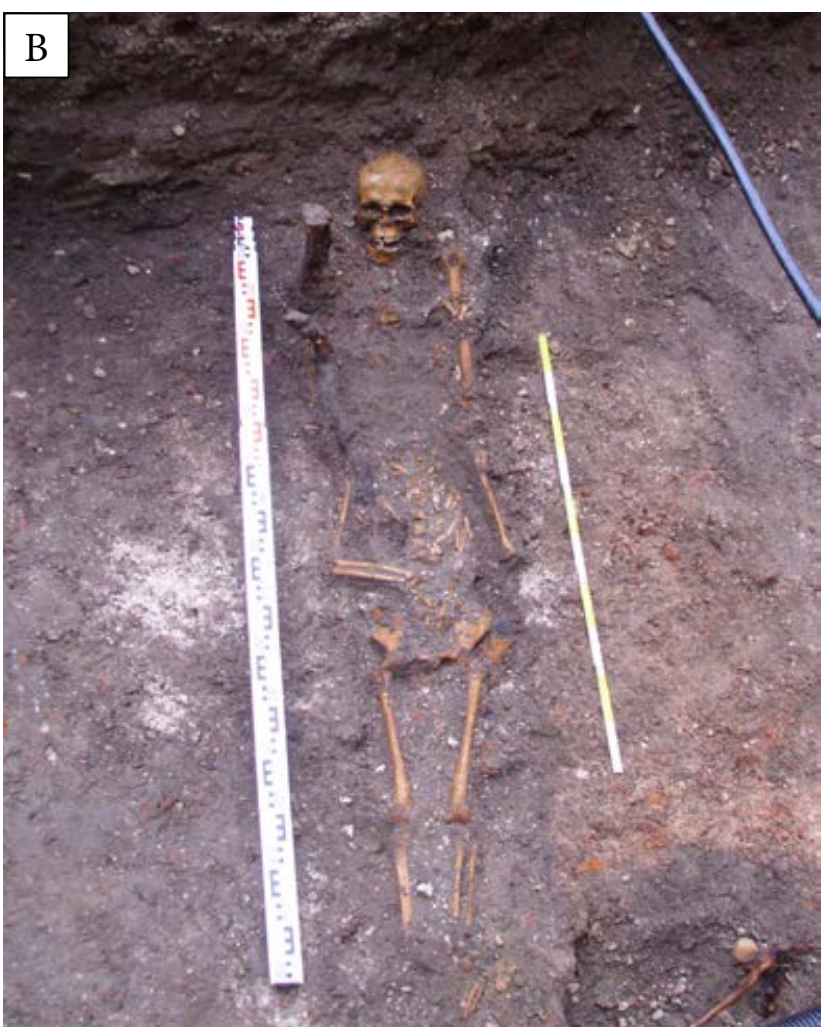

Fig. 9. Late-medieval (A) and modern graves (B) and ossuary (C) 

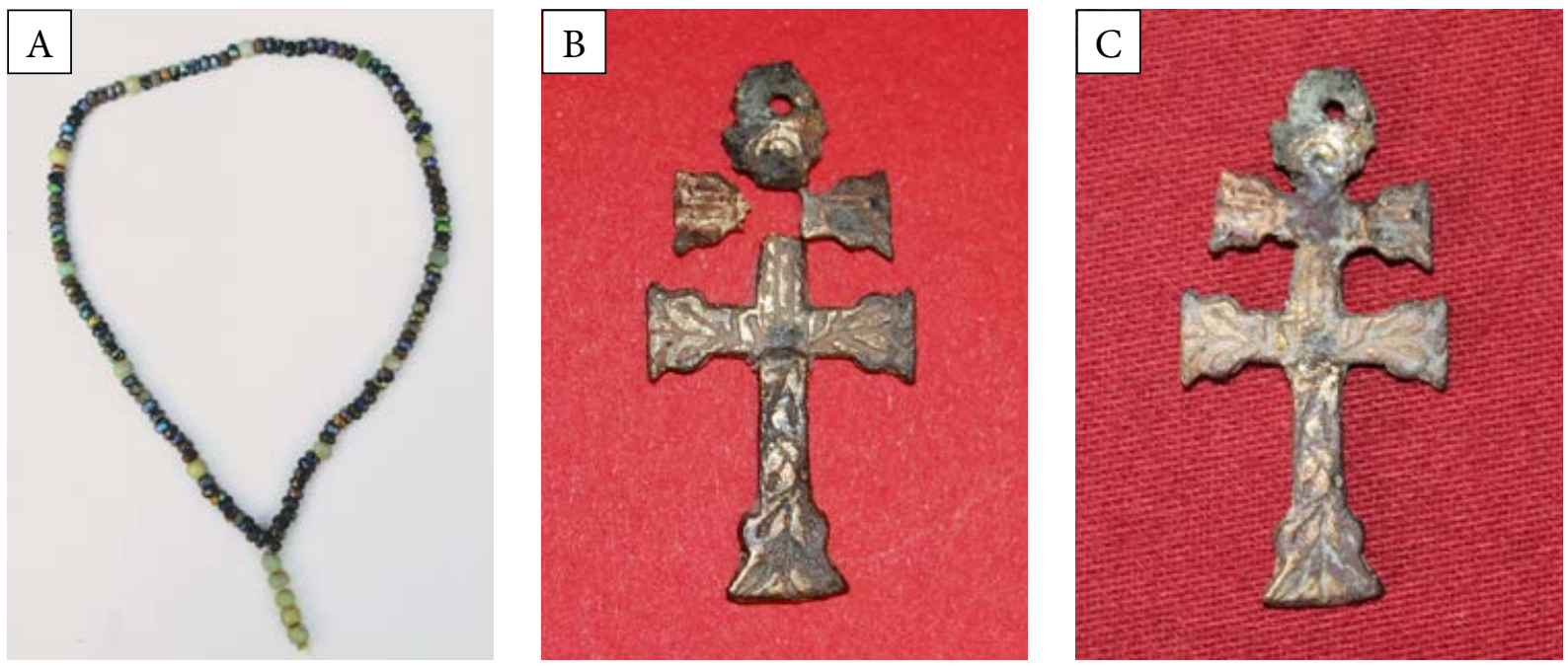

Fig. 10. Rosary (A) and choleric cross (caravaca) - before (B) and after (C) conservation - from a modern grave; photo: A, B-M. Przybyła

of large osteophytes in the form of so-called parrot beaks. In addition, the man's temporal bones had very long styloid processes, suggesting that he could also have suffered from the Eagle syndrome, which is manifested by a strong, paroxysmal pain around the ear and throat. Wider anthropological recognition will be possible after the analysis of bones collected in the 2012 season.

Geochemical studies, conducted by Marta Wardas-Lason from the AGH University of Science and Technology are in process; their purpose is to determine the impact of the necropolis on the contamination level of the cemetery site. The results obtained at this stage indicate that the soil has an alkaline $\mathrm{pH}$ ( $\mathrm{pH}$ much above 7.5), which is connected with the presence of limestone wall relics bonded with lime mortar. The presence of organic matter on the variability of oxidation-reduction potential (Eh) in the vertical profile of the layers was also observed. The origin of the organic substance should be associated mainly with burials, which, being subject to mineralization through decay of organic substances, consume oxygen present in the soil, resulting in reduction in the Eh value.

A very important finding in terms of the spatial development of early-mediaeval Cracow was the discovery in all four archaeological trenches of an accumulation settlement layer of thickness up to $60-70 \mathrm{~cm}$ (Fig. 11). It contained a relatively large amount of organic material, which gives it a dark brown and black colour, as well as particles of daub, and quite a large number of pottery fragments. Two dug-out objects were also connected with this layer, probably used originally as storage pits, and a small bowl-shaped kiln (Fig. 12), designed for firing lime (which was confirmed by two independent analyses conducted by M. Pawlikowski and A. Mueller-Bieniek) (Pawlikowski 2011: 117-118, Mueller-Bieniek \& Tomczyńska 2011: 157-158).

Dating of the layer was carried out based on a formal analysis of the historical material (in the form of pottery fragments) (Fig. 13) collected in the course of research work, and was conducted by Emil Zaitz from the Archaeological Museum of Cracow. Based on the analysis of the pottery and stratification, it was established that in the early Middle Ages there also operated an open settlement located in the northern foreland of the ducal suburbium called Okót. The characteristic raw material used to manufacture pottery (the $1^{\text {st }}$, the $4^{\text {th }}$, and the $6^{\text {th }}$ group of the raw material as per K. Radwanski's classification) (Radwański 1975), the forms of the vessels, and the characteristic forms of their brims prove that the settlement may originate from the $10^{\text {th }}$ century.

A very rich layer of debris, with many different signs of production activity (pottery fragments, broken animal bones, daub (composite building material made of wet clay and straw), charcoal and other plant debris, dug-out pits, production kiln) indicate that the settlement grew rapidly until at least the beginning of the $12^{\text {th }}$ century. 


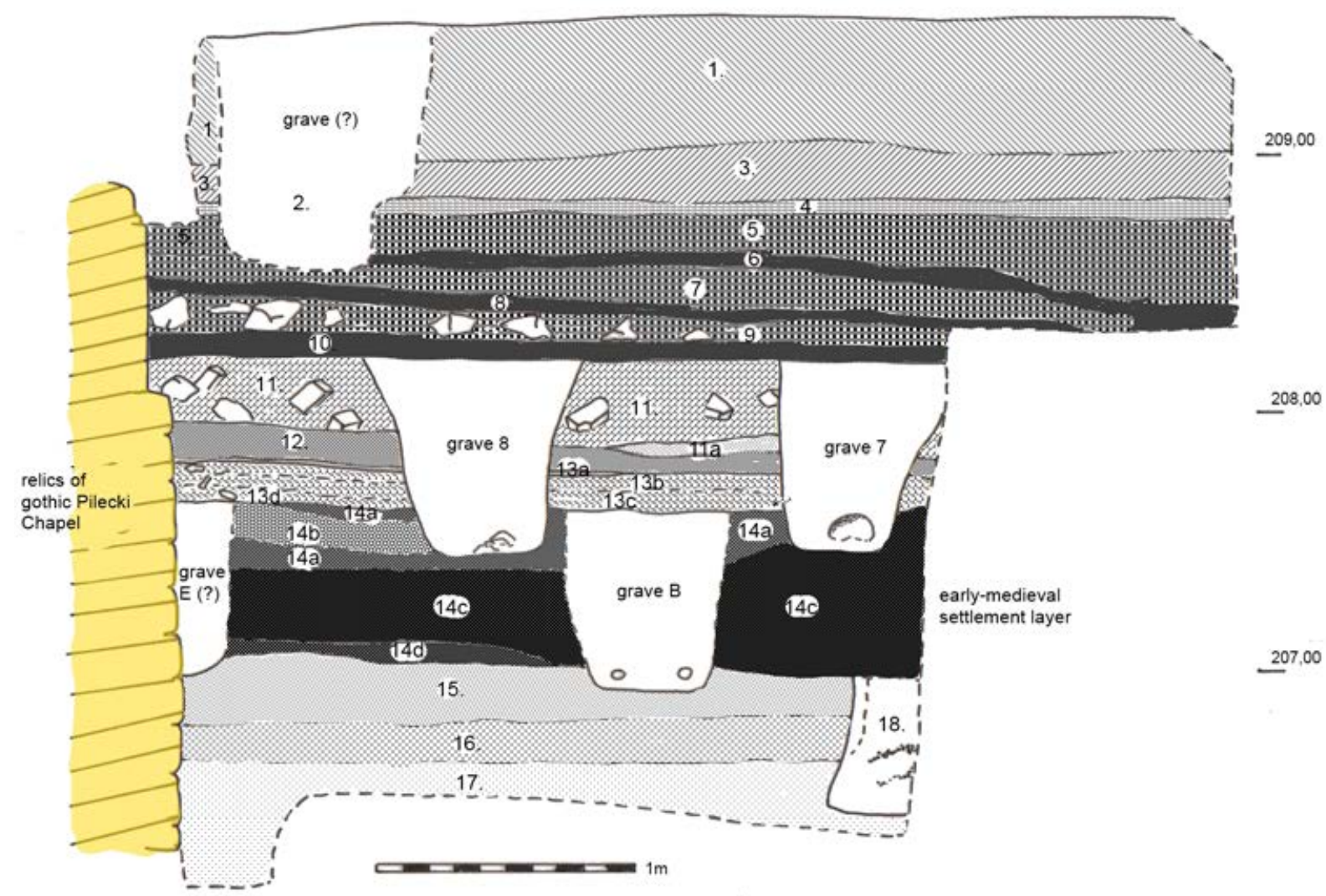

Fig. 11. Archeological cross-section with an early-medieval settlement layer visible: 1-18-archaeological layers

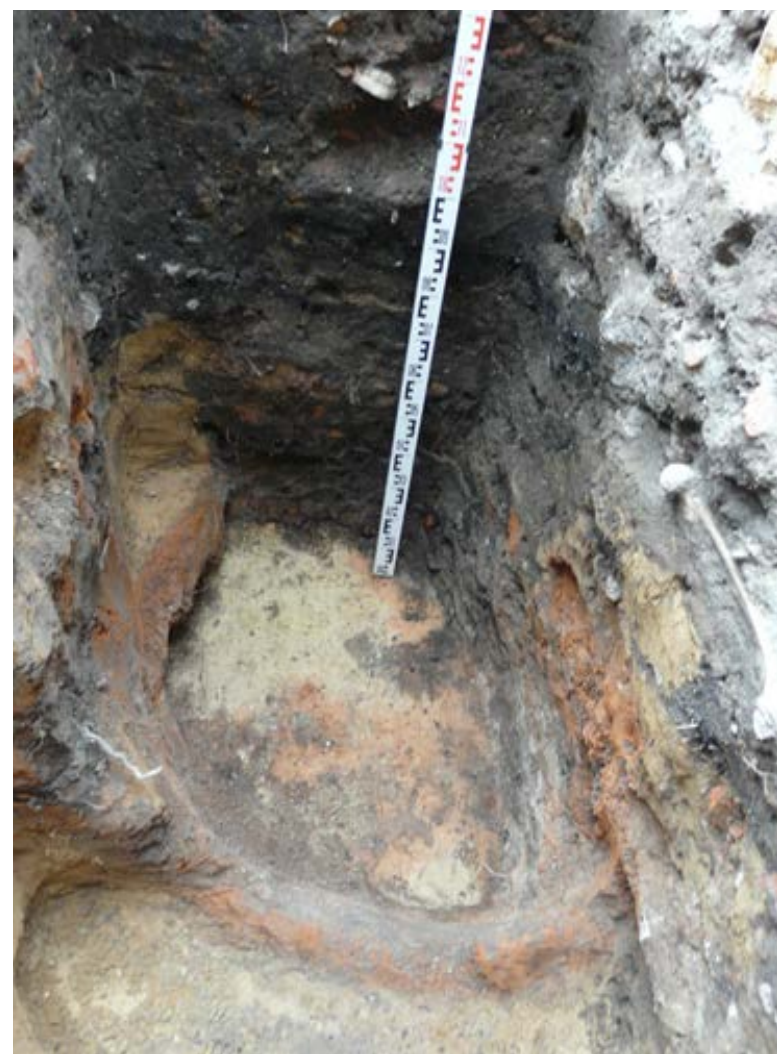

Fig. 12. Bowl-shaped lime kiln relics
No vessels typical of the middle and the second half of the $12^{\text {th }}$ century (i.e. as per K. Radwanski's type 9) suggest that the origin of the parish church and the cemetery changed the purpose and method of use of the research area. It should be noted that individual fragments of vessels of much earlier origin were also present on the site. These finds enabled the assumption of at least the occasional presence of Vistulan settlements before the $10^{\text {th }}$ century, remains of which were later destroyed by early-medieval settlement. The latter existed until the construction of the pre-Dominican parish church.

From the documented cultural strata and production levels, a relatively large quantity of animal bones were acquired; they were subject to osteological analysis conducted by Jarosław Wilczyński from the Institute of Systematics and Evolution of Animals, Polish Academy of Sciences (Wilczyński 2011: 147-149, 2012: 150-155). On this basis it was established that among the bone remains there were mainly cattle bones, with some pig, goat, or sheep bones. Among them, there were also individual bones of domestic fowl (chickens 

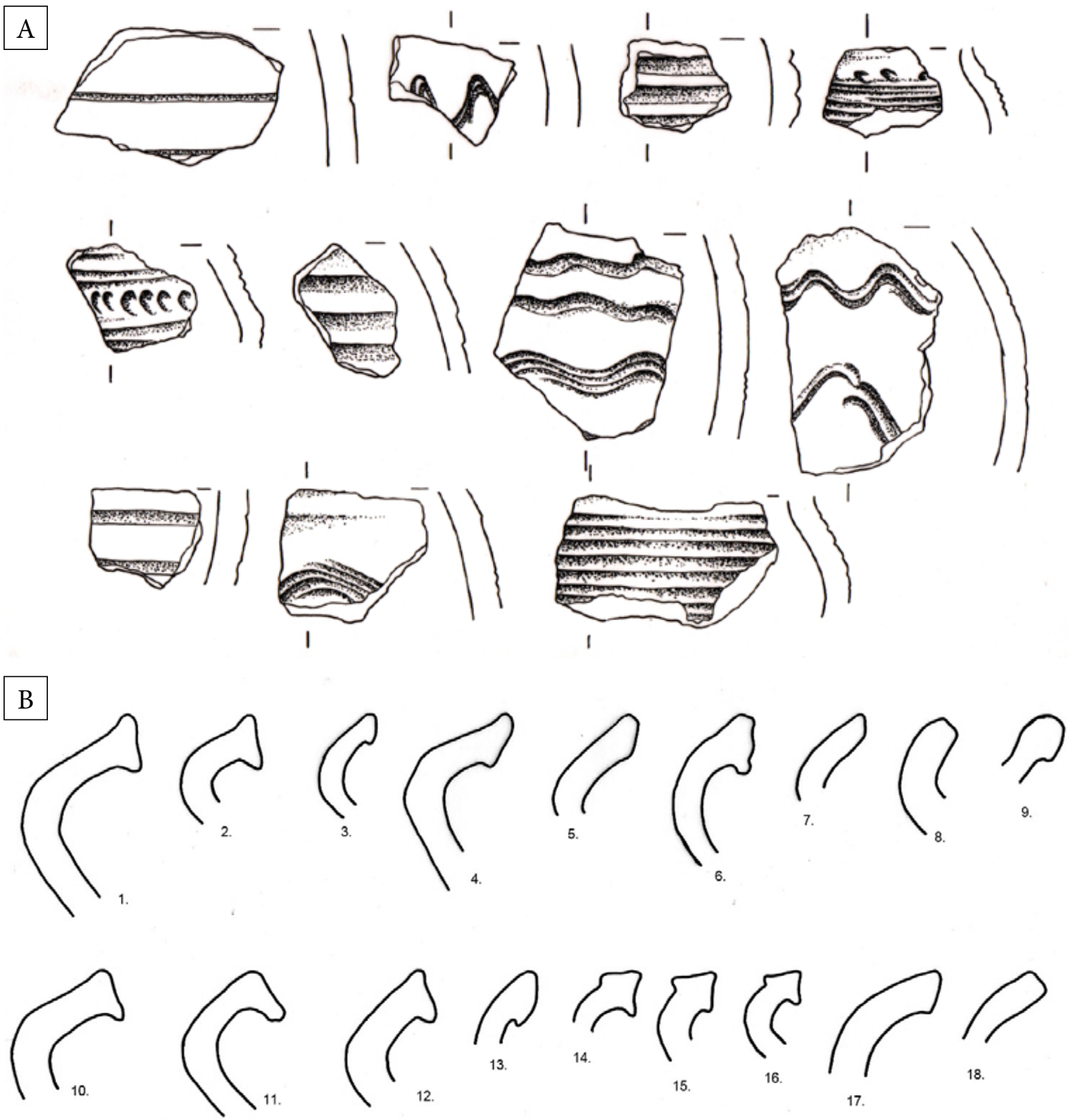

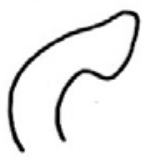

19.

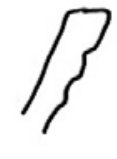

20.

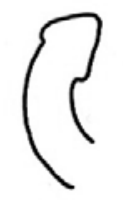

21.

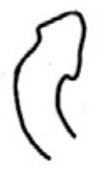

22.

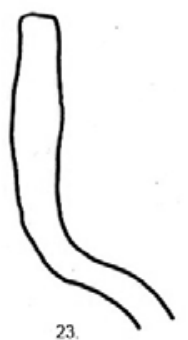

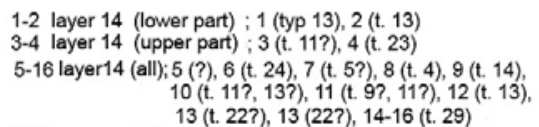

1-2 layer 14 (lower part) ; 1 (typ 13), 2 (t. 13) 3-4 layer 14 (upper part); 3 (t. 11?), 4 (t. 23) 5-16 layer14 (all); 5 (?), 6 (t. 24), 7 (t. 5?), 8 (t. 4), 9 (t. 14), 13 (t. 22?), 13 (22?), 14-16 (t. 29) $17-18$ graves $8-10 ; 17$ (t. 18?), 18 (t. 4 ) $19-20$ graves $13-15$; 19 (t. 23), 20 (t. 41) 21-23 mixed layer; 20 (t. 29), 21-22 (t. 30), 23 (t. 49?)

Fig. 13. Early-medieval decorated pottery (A) and rim-types (B)

and geese), a dog, and fish scales and metatarsal bones, probably belonging to a deer (Fig. 14). The material contained clear traces of human activity in the form of carcass split (cutting, chopping) and singe. These demonstrate that the examined skeletal remains were post-consumption waste, while the occasionally appearing traces of chewing by dogs are usually visible on material coming 
from the settlements, especially mediaeval towns. A large percentage of domestic mammal remains show that they constituted the basic meat component of the diet of mediaeval Cracovians, but some traces of chase game, birds, and fish indicate that they also played some role of the population nutrition.

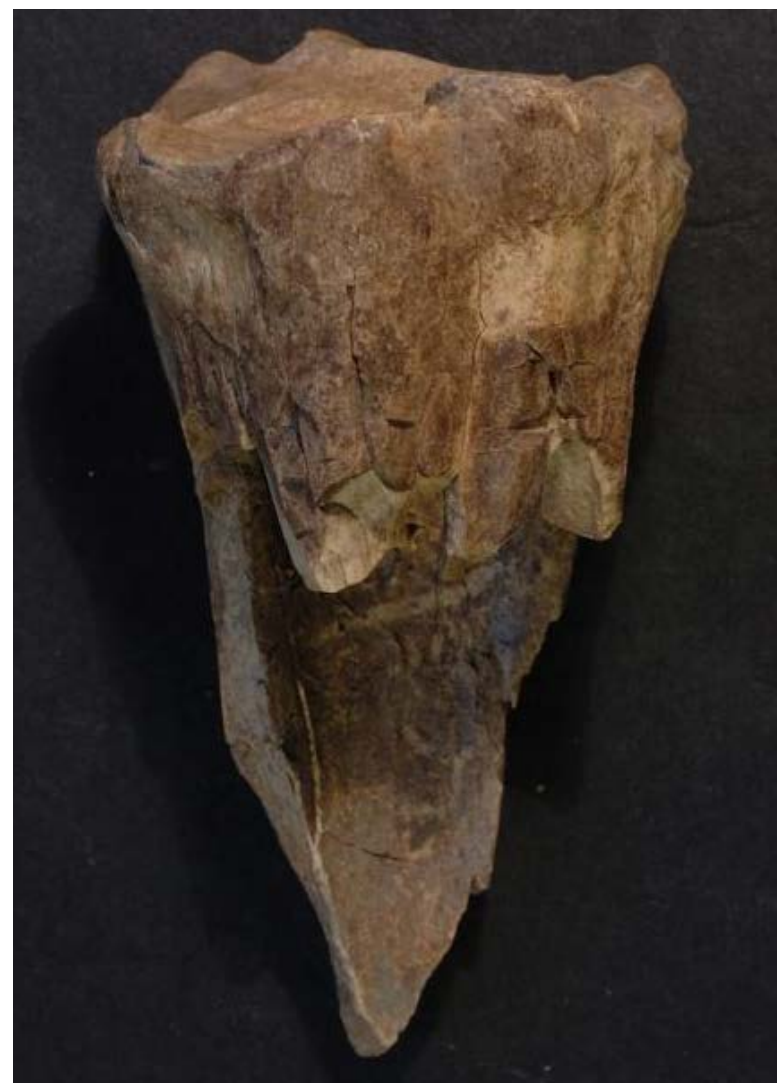

Fig. 14. Deer bone with cut marks; photo - J. Wilczyński

The analysed medieval fauna complex in terms of species is typical for mediaeval Polish towns - including Cracow - while the proportions of particular species (including the prevalence of cattle) possibly result from the small amount of material collected in which the high percentage of cattle remains is random. The dominance of the cattle remains over other species of farm animals was also present within the layers of the so-called first early-mediaeval level (the $10^{\text {th }}-12^{\text {th }}$ century) captured in archaeological trench A during the research carried out in the Main Square in Cracow in the years 2005-2007 (see Wojtal et al. 2010: 138, 149, Figs 1 and 20); particularly many remains of cow skeletons (primarily wing bones) were also found in the late-mediaeval layers in the Small Market Square in Cracow, which according to the researchers indicated that beef trade was predominant in the late-mediaeval meat market located in the Small Market Square (see Zaitz 2009: 48).

The paleobotanical material is also typical of early-mediaeval Cracow; it was analysed by Aldona Mueller-Bieniek from the W. Szafer Institute of Botanics of the Polish Academy of Sciences (Mueller-Bieniek \& Tomczyńska 2011: 156-162, Mueller-Bieniek 2012: 140-145). The samples contain traces of cereals with a majority of millet (Panicum miliaceum L.) and wild crop plants. The most numerous were millet grasses (grains of millet and foxtail (Setaria italica) cannot be excluded), and white pigweed (Chenopodium album). They were consumed thanks to their edible fruit or seeds, or used for therapeutic purposes. In one of the samples charcoal coming from spindle wood (Euonymus) was recognised, which in the archaeological context occurs very rarely, even though it is a plant native to the local flora; the presence of this interesting taxon would require confirmation.

Thanks to the paleobotanical analysis, the presence of an original humus layer was confirmed, in which no crop diaspora were detected, while numerous sclerotia of mycorrhical soil fungus Cenococcum geophilum were found. Its presence may indicate there was a wooded area on the research site.

\section{CONCLUSIONS}

These research results, described as interdisciplinary and traditionally perceived as "supplementary" in the exploration and interpretation of the stricte archaeological excavations, show that, despite the very limited study area (the total area of excavations is just c. $16 \mathrm{~m}^{2}$ ), and the relatively harsh conditions of the operation (simultaneous, ongoing renovation and construction works, necessary surveys executed in hard to reach places such as drainage channels), it is possible to obtain a great deal of very important information, imperceptible by traditional, archaeological methods. The interdisciplinary cooperation has also enabled a more complete interpretation of the archaeological and architectural finds. 


\section{REFERENCES}

Długosz J., 1964-1974. Roczniki, czyli kroniki sławnego Królestwa Polskiego. Księga 6. Warszawa.

Długosz J., 1863-1864. Liber beneficiorum dioecesis Cracoviensis. Tomus 3. Kraków.

Kuczera S., 2012. Opinia geotechniczna. Rozpoznanie geotechniczne podłoża gruntowego i analiza występujących nawarstwień w rejonie kruchty kościoła św. Trójcy w Krakowie przy ulicy Stolarskiej 12, dzielnica I - Stare Miasto. [in:] Łyczak M. \& Górski R., Wyniki badań archeologicznych prowadzonych $w$ rejonie bazyliki św. Trójcy na terenie Placu Dominikańskiego w Krakowie (etap II - część pótnocna i środkowa Placu), Kraków [typescript in the archives of Wojewódzki Urząd Ochrony Zabytków in Cracow], 110-139.

Kuraś S. (wyd.), Zbiór dokumentów katedry i diecezji krakowskiej.

Łyczak M. \& Górski R., 2011. Wyniki badań archeologicznych prowadzonych $w$ rejonie bazyliki św. Trójcy na terenie Placu Dominikańskiego w Krakowie (etap I - czesść południowa Placu). Kraków [typescript in the archives of Wojewódzki Urząd Ochrony Zabytków in Cracow].

Łyczak M. \& Górski R., 2012a. Ratownicze badania wykopaliskowe $\mathrm{w}$ rejonie bazyliki św. Trójcy na terenie południowej części Placu Dominikańskiego w Krakowie. Krzysztofory - Zeszyty Naukowe Muzeum Historycznego Miasta Krakowa, 30, 235-242.

Łyczak M. \& Górski R., 2012b. Wyniki badań archeologicznych prowadzonych $w$ rejonie bazyliki św. Trójcy na terenie Placu Dominikańskiego w Krakowie (etap II - częśc pótnocna i środkowa Placu), Kraków [typescript in the archives of Wojewódzki Urząd Ochrony Zabytków in Cracow], 3-86.

Łyczak M. \& Górski R., 2013. Wyniki badań archeologicznych prowadzonych w rejonie bazyliki św. Trójcy na terenie Placu Dominikańskiego w Krakowie (etap I - część południowa Placu). [in:] Markiewicz A., Szyma M. \& Walczak M. (red.), Sztuka w kręgu krakowskich dominikanów, Kraków, 235-256.

Mueller-Bieniek A. \& Tomczyńska Z., 2011. Analiza makroszczątków roślinnych pobranych z nawarstwień historycznych w trakcie badań archeologicznych w rejonie fasady kościoła św. Trójcy w Krakowie. [in:] Łyczak M. \& Górski R., Wyniki badań archeologicznych prowadzonych $w$ rejonie bazyliki św. Trójcy na terenie Placu Dominikańskiego w Krakowie (etap I - część południowa Pla$c u)$, Kraków [typescript in the archives of Wojewódzki Urząd Ochrony Zabytków in Cracow], 156-162.

Mueller-Bieniek A., 2012. Raport z badań archeobotanicznych próbek pobranych z Placu Dominikanskiego (wykop III) w Krakowie. [in:] Łyczak M. \& Górski R., Wyniki badań archeologicznych prowadzonych $w$ rejonie bazyliki św. Trójcy na terenie Placu Dominikańskiego w Krakowie (etap II - część pótnocna i środkowa Placu), Kraków [typescript in the archives of Wojewódzki Urząd Ochrony Zabytków in Cracow], 140-145.

Myszka M., 2003. Dawne cmentarze Krakowa w świetle badań archeologicznych. Krakowska Teka Konserwatorska, 3, 121-143.

Nawrocki W., 2011. Badania georadarowe wykonane przed zachodniq elewacja kościoła oo. Dominikanów pw. św. Trójcy. ZBN KPG Sp. z o.o., Kraków [typescript in the archives of Dominican monastery in Cracow].

Niewalda W. \& Rojkowska H., 2012. Najstarsze relikty kościoła św. Trójcy oraz kaplicy grobowej Pileckich odkryte przed zachodnią elewacją kościoła dominikanów w Krakowie. Krzysztofory - Zeszyty Naukowe Muzeum Historycznego Miasta Krakowa, 30, 243-250.

Pawlikowski M., 2011. Wyniki badań mineralogiczno-petrograficznych próbek skał i zapraw z obiektów architektonicznych (wykop archeologiczny między wejściem do kościoła Dominikanów a ul. Sienną). [in:] Łyczak M. \& Górski R., Wyniki badań archeologicznych prowadzonych $w$ rejonie bazyliki św. Trójcy na terenie Placu Dominikańskiego w Krakowie (etap I - część południowa Pla$c u$ ), Kraków [typescript in the archives of Wojewódzki Urząd Ochrony Zabytków in Cracow], 93-118.

Pawlikowski M., 2012. Wyniki badań mineralogiczno-petrograficznych próbek skał i zapraw z obiektów architektonicznych (wykop archeologiczny między wejściem do kościoła Dominikanów a kramami przy ulicy Stolarskiej). [in:] Łyczak M. \& Górski R., Wyniki badań archeologicznych prowadzonych $w$ rejonie bazyliki św. Trójcy na terenie Placu Dominikańskiego $w$ Krakowie (etap II część pólnocna i środkowa Placu), Kraków [typescript in the archives of Wojewódzki Urząd Ochrony Zabytków in Cracow], 87-109.

Radwański K., 1975. Kraków przedlokacyjny. Rozwój przestrzenny. PTAiN, Kraków.

Rajman J., 2004. Kraków. Zespół osadniczy, proces lokacji, mieszczanie do roku 1333. Wydawnictwo Naukowe Akademii Pedagogicznej, Kraków.

Rocznik kapituły krakowskiej, 1978. [in:] Kozłowska-Budkowa Z. (ed.), Annales Cracovienses priores cum kalendario = Najdawniejsze roczniki krakowskie i kalendarz, series: Monumenta Poloniae Historica. Series Nova, 5, Państwowe Wydawnictwo Naukowe, Warszawa, 19-105.

Rojkowska H., 2013. Teren dawnego cmentarza św. Trójcy. Przemiany przestrzenne. [in:] Markiewicz A., Szyma M. \& Walczak M. (red.), Sztuka w kręgu krakowskich dominikanów, Wydawnictwo Esprit, Kraków, 211-234.

Szczepanek A., 2011. Analiza antropologiczna szkieletów z Placu Dominikańskiego - badania 2011 r. [in:] Łyczak M. \& Górski R., Wyniki badań archeologicznych prowadzonych $w$ rejonie bazyliki św. Trójcy na terenie Placu Dominikańskiego w Krakowie (etap I - część południowa Placu), Kraków [typescript in the archives of Wojewódzki Urząd Ochrony Zabytków in Cracow], 119-148.

Szczepanek A., 2012. Szkielety z Placu Dominikańskiego - wyniki analizy antropologicznej. [in:] Łyczak M. \& Górski R., Wyniki badań archeologicznych prowadzonych $w$ rejonie bazyliki św. Trójcy na terenie Placu Dominikańskiego w Krakowie (etap II - część pótnocna $i$ środkowa Placu), Kraków [typescript in the archives of Wojewódzki Urząd Ochrony Zabytków in Cracow], $150-154$.

Szyma M., 2012. Kaplica Kazimierza Wielkiego przy krakowskim kościele Dominikanów. [in:] Bukowski W. \& Jurek T. (red.), Narodziny Rzeczypospolitej. Studia $z$ dziejów średniowiecza i czasów wczesnonowożytnych, Wydawnictwo Towarzystwa Naukowego Societas Vistulana, Kraków, 961-980. 
Turkiewicz P., 2011. Inwentaryzacja wykopu archeologicznego przed wejściem do nawy pd. Bazyliki Świętej Trójcy $w$ Krakowie. Kraków [typescript in the archives of Dominican monastery in Cracow].

Turkiewicz P., 2012. Inwentaryzacja wykopu archeologicznego przed wejściem do nawy pn. Bazyliki Świętej Trójcy $w$ Krakowie. Kraków [typescript in the archives of Dominican monastery in Cracow].

Wilczyński J., 2011. Wyniki badań zooarcheologicznych szczątków kostnych z badań wykopaliskowych prowadzonych przy kościele św. Trójcy w Krakowie w 2011 roku. [in:] Łyczak M. \& Górski R., Wyniki badań archeologicznych prowadzonych $w$ rejonie bazyliki św. Trójcy na terenie Placu Dominikańskiego w Krakowie (etap I - część potudniowa Placu), Kraków [typescript in the archives of Wojewódzki Urząd Ochrony Zabytków in Cracow], 150-155.

Wilczyński J., 2012. Wyniki badań zooarcheologicznych szczątków kostnych z badań wykopaliskowych prowadzonych przy kościele św. Trójcy w Krakowie w 2012 roku. [in:] Łyczak M. \& Górski R., Wyniki badań archeologicznych prowadzonych $w$ rejonie bazyliki św. Trójcy na terenie Placu Dominikańskiego w Krakowie (etap II - część północna i środkowa Placu), Kraków [typescript in the archives of Wojewódzki Urząd Ochrony Zabytków in Cracow], 147-149.

Wojtal P., Makowiecki D., Wertz K., Wilczyński J., Miękina B. \& Zabilska B., 2010. Wstępne wyniki badań zooarcheologicznych szczątków kostnych z wykopalisk prowadzonych na Rynku krakowskim w latach 2005-2007. Krzysztofory - Zeszyty Naukowe Muzeum Historycznego Miasta Krakowa, 28, 2, 137-150.

Zaitz E., 1974. Kraków-Śródmieście. Klasztor OO Dominikanów. Informator Archeologiczny. Badania, 8, 236-238.

Radwańska T., Zaitz E., Reyniak J., 1975. Kraków-Śródmieście. Klasztor OO Dominikanów. Informator Archeologiczny. Badania, 9, 187-188.

Zaitz E., 2006. Osadnictwo wczesnośredniowieczne na terenie Krakowa. [in:] Firlet Z. \& Zaitz E. (red.), Kraków w chrześcijańskiej Europie X-XIII w.: katalog wystawy, Muzeum Historyczne Miasta Krakowa, Kraków, 220-272.

Zaitz E., 2009. Wyniki badań archeologicznych przeprowadzonych przy przebudowie nawierzchni Małego Rynku w 2007 r. Materiały Archeologiczne, 37, 35-92. 